\title{
Dentate Hilar Cells with Dendrites in the Molecular Layer Have Lower Thresholds for Synaptic Activation by Perforant Path than Granule Cells
}

\author{
Helen E. Scharfman ${ }^{a}$ \\ Howard Hughes Medical Institute, Department of Neurobiology and Behavior, SUNY at Stony Brook, Stony Brook, New \\ York 11794
}

\begin{abstract}
Neurons in the dentate hilus or area CA3C of rat hippocampal slices were recorded intracellularly with electrodes containing the fluorescent dye Lucifer yellow. Stimulation of perforant path fibers in the molecular layer of the fascia dentata strongly excited most hilar neurons, with a much lower threshold for action potential generation than granule cells and area CA3c pyramidal cells that were recorded in the same area of the slice. Examination of dye-filled hilar neurons with a confocal microscope showed that hilar cells with a low threshold were morphologically heterogeneous: some were spiny "mossy" cells, and others were aspiny interneurons. However, all hilar cells with low thresholds possessed dendrites that penetrated the granule cell layer and passed into the molecular layer, often reaching the outer molecular layer. The few hilar cells that had a threshold similar to, or greater than, granule cells did not possess visible dendrites in the molecular layer.

The results suggest that the circuitry of the dentate region allows for (1) excitation of both granule cells and hilar cells by perforant path stimuli, and (2) strong excitation of most hilar cells when most granule cells are subthreshold for action potential generation. Given that hilar neurons project to many different sites in the ipsilateral and contralateral fascia dentata (Blackstad, 1956; Zimmer, 1971; Swanson et al., 1978; Laurberg and Sørensen, 1981), it is quite likely that hilar neurons are involved in the processing of information passing from entorhinal cortex to hippocampus.
\end{abstract}

Studies of the effects of prolonged perforant path stimulation have shown that most hilar cells of the rat fascia dentata are damaged following sustained excitation, whereas neighboring granule cells remain intact (Olney et al., 1983; Sloviter, 1983, 1987; Scharfman and Schwartzkroin, 1989, 1990). This is an important experimental model of excitotoxicity, because dramatic hilar cell loss is reported in diseases such as temporal lobe epilepsy (Meldrum and Corsellis, 1985), as well as after brief periods of ischemia (Johansen et al., 1987; Benveniste and Diemer, 1988; Crain et al., 1989). The selective vulnerability of

\footnotetext{
Received Sept. 12, 1990; revised Nov. 29, 1990; accepted Jan. 18, 1991.

This study was supported by the Howard Hughes Medical Institute. I am grateful to Paul Adams for his support and suggestions. I also thank Robert Sloviter for helpful comments on the manuscript. The technical expertise of Barry Burbach and David Printzenhoff was greatly appreciated.

a Present and correspondence address: Helen E. Scharfman, Neurology Research Center, Helen Hayes Hospital, West Haverstraw, NY 10993-1195.

Copyright (C) 1991 Society for Neuroscience $0270-6474 / 91 / 111660-14 \$ 03.00 / 0$
}

hilar cells may be due to the lack of calcium-binding proteins in hilar cells, which has been demonstrated immunocytochemically (Baimbridge and Miller, 1982; Kosaka et al., 1987; Sloviter, 1989). However, very little is known about physiology of hilar cells or the circuitry involved in their excitation and inhibition.

Therefore, hilar cells were recorded intracellularly in hippocampal slices, and their responses to single stimuli of the outer molecular layer were examined. Hilar cell responses were compared to the responses of granule cells and area CA $3 \mathrm{c}$ pyramidal cells in the same slice. To determine whether aspects of hilar neuronal morphology might help to explain their physiological responses, hilar neurons were injected with the fluorescent dye Lucifer yellow during the recording procedure and examined subsequently by confocal microscopy.

\section{Materials and Methods}

Preparation and maintenance of hippocampal slices

Slices were obtained from male or female adult Sprague-Dawley rats (100-150 gm; Charles River) and maintained in warmed $\left(35^{\circ} \mathrm{C}\right)$, oxygenated $\left(95 \% \mathrm{O}_{2}, 5 \% \mathrm{CO}_{2}\right)$ buffer (in mM: $125.0 \mathrm{NaCl}, 5.0 \mathrm{KCl}, 2.0$ $\mathrm{CaCl}_{2}, 2.0 \mathrm{MgSO}_{4}, 26.0 \mathrm{NaHCO}_{3}, 1.25 \mathrm{NaH}_{2} \mathrm{PO}_{4}$, and $10.0 \mathrm{~d}$-glucose; $\mathrm{pH}, 7.4$ ) as described previously (Scharfman and Schwartzkroin, 1990).

\section{Intracellular recording and stimulation}

Extracellular and intracellular recording methods were similar to those described previously (Scharfman and Schwartzkroin, 1990). Extraccllular recording electrodes were made from borosilicate, capillary-filled glass (0.6-mm inner diameter, 1.0-mm outer diameter; World Precision Instruments), on a horizontal Brown-Flaming puller (Model P-80/PC, Sutter Instruments). Electrodes were filled with $1 \mathrm{M} \mathrm{NaCl}$, and resistances were 2-15 M . NaCl-filled electrodes with such low resistances were discarded if any hint of leakage from the tip occurred while testing the electrode in the CAl pyramidal cell layer. Such leakage is easily detected because of a rapid deterioration in the extracellularly recorded field potential and change in opacity of the tissue around the recording electrode.

The tips of intracellular recording electrodes were initially backfilled in a filtered solution of $1.5 \%$ Lucifer yellow CH (Sigma) dissolved in 1 M LiCl. The shaft of the electrode was subsequently filled with $1 \mathbf{~ M ~ L i C l}$. Resistances of these electrodes were 80-120 M . A high input impedance intracellular amplifier (Axoclamp-2A, Axon Instruments) was used for intracellular recording, and the bridge was balanced whenever DC current was used to manipulate the membrane potential of the recorded neuron. An oscilloscope (model 5111A, Tektronix) was used to monitor recordings, and data were digitized (VR-10 Digital Data Recorder, Instrutech) and stored on tape (VCR model VC-120T, Toshiba) for later analysis.

Resting membrane potential (RMP), input resistance $\left(R_{\text {in }}\right)$, and time constants were measured as described previously (Scharfman and Schwartzkroin, 1988). 


\section{Responses to stimulation of the perforant path}

The perforant path was stimulated by gently placing a bipolar stimulating electrode on the surface of the slice in the outer molecular layer, at least $500 \mu \mathrm{m}$ from the recording sites. The distance of the stimulating electrode to the nearest part of the granule cell layer was $200-300 \mu \mathrm{m}$. The tips were placed so that they were as close as possible to the hippocampal fissure, and at a slight angle to the fissure, so that they would activate many fibers in the outer molecular layer without directly activating granule cells (Fig. $1 B$ ). The electrodes were made from tightly twisting two pieces of Teflon-coated, stainless-steel wire $(150-\mu \mathrm{m}$ diameter; Medwire Co., Mt. Vernon, NY) together. A stimulus isolator unit (model 805, World Precision Instruments) was used to apply current pulses $(50-250 \mu \mathrm{A}, 50 \mu \mathrm{sec}$, stimulus frequency below $0.2 \mathrm{~Hz}$ ) to the stimulation site

As shown by many investigators (Andersen et al., 1966, 1971; Lomo, 1971), the response recorded extracellularly in the granule cell layer upon stimulation of the perforant path is composed of a positive wave (representing the sum of subthreshold potentials in the cells surrounding the recording electrode; the "population EPSP") and a sharp negativegoing deflection superimposed on the population EPSP (the "population spike"; see Fig. $(B-D)$. The population spike was optimized at every recording site by placing the recording electrode on the border of the hilus and the granule cell layer (the site where granule cell axons enter the hilus) and by slowly advancing the electrode to the depth in the slice where the largest population spike was recorded (typically 50-150 $\mu \mathrm{m}$ deep). Population spikes were recorded on the border of the granule cell layer and the hilus, instead of the center of the granule cell layer or near the border of the granule cell layer and the molecular layer, because the latter two recording sites yield population responses that are a mixture of the somatic and dendritic potentials of granule cells (Lømo, 1971). In contrast, recordings taken at the border of the granule cell layer and the hilus reflect action potential (AP) activity primarily. In practice, both the population EPSP and the population spike recorded near the molecular layer were never as large as responses recorded at the border of the granule cell layer and the hilus. However, the threshold for the population spike was similar regardless of whether it was recorded near the hilus or near the molecular layer. By projecting a strong light (Fiberlite, Dolan Jenner Industries) on the slice, the borders of the granule cell layer were easily discerned.

Slices were not used if the maximal population EPSP was less than $5 \mathrm{mV}$ (measured from baseline to peak), the maximal population spike was less than $5 \mathrm{mV}$ (measured as in Fig. 1D), or there was an absence of paired-pulse inhibition. Paired-pulse inhibition was tested at the beginning of each experiment to ensure that some of the vital inhibitory circuitry of the fascia dentata was functional in the slice. Paired-pulse inhibition was tested by triggering two identical, intermediate-strength stimuli (i.e., one that produced a $2-4-\mathrm{mV}$ population spike) $10 \mathrm{msec}$ apart (Fig. 1C). If the second stimulus produced a much smaller population spike than the first stimulus, paired-pulse inhibition was judged to be satisfactory (Fig. 1C).

It has been shown that the lateral perforant path fibers lie in the outer molecular layer and that the medial perforant path fibers lie in the middle third of the molecular layer (Hjorth-Simonsen, 1973; Steward and Scoville, 1976). When the lateral perforant path is activated, the population spike occurs on the falling phase of the population EPSP (McNaughton and Barnes, 1977). Because the outer molecular layer was stimulated in our experiments, and because most population spikes recorded were superimposed on the falling phase of the population EPSP, it is likely that the lateral perforant path was activated preferentially. However, in a few experiments the population spike fell on the rising phase of the population EPSP, and therefore it is likely that some medial perforant path fibers were activated in those cases. Importantly, the comparisons of thresholds appear to be the same in all experiments, regardless of whether the lateral or medial perforant path was activated or whether recordings were made in dorsal or ventral hippocampus.

It is important to note that stimulation of the outer molecular layer may not only activate perforant path axons, because other fibers besides perforant path axons (though few in comparison to perforant path axons) are present in the outer molecular layer. For example, the axons of somatostatin-immunoreactive and neuropeptide $\mathrm{Y}$-immunoreactive aspiny hilar cells have plexuses in the molecular layer (Köhler et al., 1982, 1986; Sloviter and Nilaver, 1987; Naus et al., 1988). However, it is unlikely that these peptidergic cells were stimulated in these experiments, because antidromic action potentials were never recorded from a hilar cell following stimulation of the outer molecular layer. It is also unlikely that current spread from the stimulating electrode into the inner molecular layer antidromically activated hilar cells, because the hilar cells that innervate the inner molecular layer are quite distant from their ipsilateral and contralateral targets (Zimmer, 1971; Swanson et al., 1978; Laurberg and Sørensen, 1981; Amaral and Witter, 1989). It is unlikely that both the cell bodies and the axons from these hilar cells would be maintaincd in a slice preparation.

\section{Measurement of threshold}

Extracellular recording. Based on early studies of hippocampal physiology (Andersen et al., 1971), the population spike was used as a sample of the activity of a number of granule cells surrounding the extracellular recording electrode. Therefore, it was assumed that the stimulus intensity used to elicit a negative inflection on the population EPSP (i.e., a $1-2-\mathrm{mV}$ population spike; Fig. $1 B$ ) was the stimulus intensity required by many granule cells to reach threshold for action potential generation. This assumption was borne out by preliminary experiments where the threshold of an intracellularly recorded granule cell was compared to the threshold of the extracellularly recorded population spike, in a situation where the extracellular and intracellular recording sites were very close (Fig. 1D). In these experiments, the threshold for a population spike was equivalent to the threshold for the impaled granule cell (Fig. $1 D$ ). Therefore, threshold of the granule cell population spike was defined as the stimulus intensity necessary to elicit a small $(1-2-\mathrm{mV})$ population spike. Slices were not used if the granule cell population spike threshold was indistinct (i.e., if a wide range of stimulus intensities elicited only a small population spike). Only when the threshold of the population spike could be pinpointed to a specific stimulus strength was the slice used. Many extracellular recording sites in the granule cell layer were tested near the impaled cell (Fig. $1 B$ ) so that any irregularities (areas where the granule cell threshold might be unusually low or high) were found. In practice, no such irregularities were found, and the thresholds for the population spikes were similar for the range of sites tested in each slice (Fig. 1B).

Intracellular recording. The threshold of the granule cell population spike was compared to the threshold of hilar neurons by recording from the hilar cell and the granule cell layer simultaneously. Cells were tested at their RMP, which was between -50 and $-70 \mathrm{mV}$. Threshold for the cell was defined as the stimulus strength required to elicit an action potential in $50 \%$ of trials. Thrcsholds werc measured every $2-5 \mathrm{~min}$ during the intracellular recording period so that instabilities in threshold would be found. There were only three cases where threshold was unstable for the cell, and these were assumed to be a result of injury due to impalement, because these cells also had a relatively short time constant, small input resistance, and depolarized RMP relative to other cells. Therefore, these three cases are not included in the Results. However, it is important to note that, even in these unstable cells, the range of thresholds for the cell was always lower than the threshold for the population spike.

\section{Intracellular dye injection}

All cells were filled with Lucifer yellow and subsequently analyzed using light microscopy. Injection of Lucifer yellow was similar to previous reports (Scharfman and Schwartzkroin, 1988).

\section{Scanning confocal microscopy}

Slices were viewed in their entirety (i.e., without resectioning) using an inverted microscope (Zeiss IM35) that was adapted to be confocal (MRC 500 , Biorad). The slice was viewed with the coverslip between the objective (Zeiss Neofluar $16 \times$, numerical aperture 0.40 ; or Zeiss Neofluar $40 \times$, numerical aperture 0.75 ) and the section. The blue excitation filter set was used (excitor filter, 488-nm DF 10; dichroic reflector, 510-nm LP; emission filter, 515-nm LP). For each cell, 10-20 optical sections (each section was approximately $1-10 \mu \mathrm{m}$ from the next section) were made through the slice to view all of the visible processes. Photomicrographs were made with the black-and-white film pack for a video printer (UP-5000; Sony).

\section{Results}

Twenty-three neurons were recorded in 23 slices from 19 rats. All cells had RMPs over $50 \mathrm{mV}, R_{\text {in }}$ values of over $40 \mathrm{M} \Omega$, and overshooting APs. One exception to this rule was made for three 


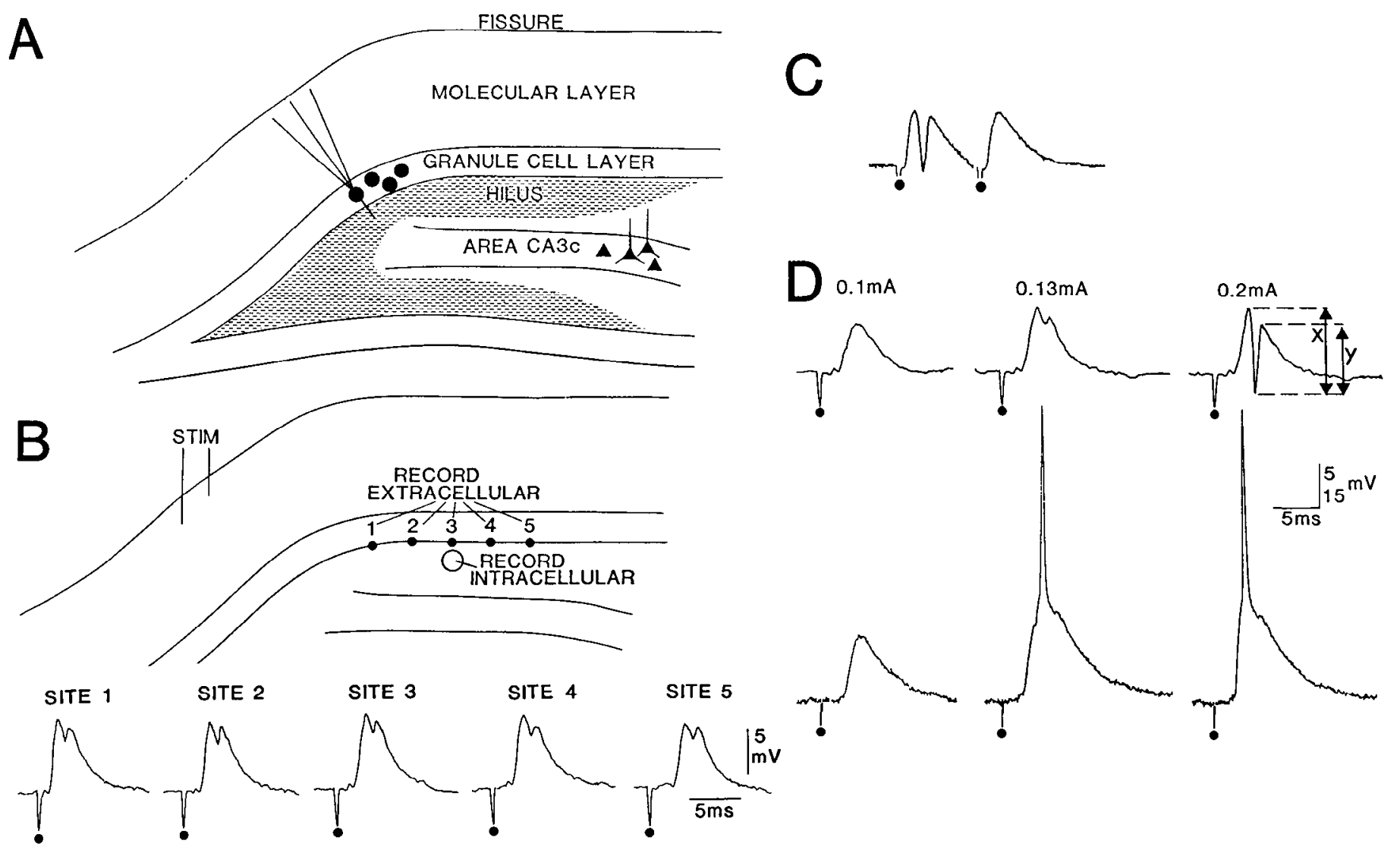

Figure 1. Terminology and methods used in the simultaneous recording of granule cell population spikes and hilar neurons. $A$, Schematic diagram of the fascia dentata. The granule cell layer, the molecular layer, and area CA $3 \mathrm{c}$ are outlined, as they would appear in a typical slice. The orientations of granule cells and pyramidal cells are illustrated. Hilus refers to the shaded region and contains cells with diverse morphologies and orientations (Amaral, 1978). B: Top, A diagram of the typical cxperimental arrangement is shown. A bipolar stimulating electrode (STIM) was placed in the outer molecular layer. There were many extracellular recording sites on the border of the granule cell layer and the hilus (solid circles; five sites are shown) and one intracellular recording site (open circle). Many extracellular recording sites were sampled in order to optimize comparison of the thresholds of many granule cells with the threshold of the impaled neuron. Bottom, Typical extracellular recordings obtained from the slice that is schematized in $B$, top. The response with the shortest latency was recorded at the site closest to the stimulating electrode (site 1), and the response with the longest latency was recorded at the site farthest from the stimulating electrode (site 5). As was typical for the slices used in this study, the responses recorded at the five different sites were similar. In $B-D$, the stimulus artifacts are clipped and marked by the small solid circles. $C$, An example of paired-pulse inhibition of the population spike. A pair of identical stimuli was triggered at the beginning of each experiment to test for the presence of paired-pulse inhibition of the population spike. When the interstimulus interval was $10 \mathrm{msec}$, the population spike after the second stimulus was much smaller (or inhibited completely, as shown) than the population spike following the first stimulus. $D$, The threshold for the population spike, recorded as shown in $B$ and $C$, was similar to the threshold of a granule cell located near the extracellular recording site. An example is shown for site 3 in the slice schematized in $B$. Simultaneous extracellular (top) and intracellular (bottom) recordings are shown following low (left; $0.1 \mathrm{~mA}$ ), intermediate (center; $0.13 \mathrm{~mA}$ ), and high (right; $0.2 \mathrm{~mA}$ ) stimulus strengths. In all experiments, stimulus durations were 50 $\mu \mathrm{sec}$. The intermediate stimulus intensity was just above threshold for a population spike and also just above threshold for the granule cell. Granule cell RMP was $-78 \mathrm{mV}$. The amplitude of the population spike was defined as the average of the two sharp deflections that comprise the population spike, as shown for the population spike elicited following the high-intensity stimulus (i.e., population spike amplitude $=$ the average of the negativegoing deflection labeled $x$ and positive-going deflection labeled $y$ ). Calibration: top traces (extracellularly recorded population spikes), $5 \mathrm{mV}, 5$ msec; bottom traces (intracellular recordings), $15 \mathrm{mV}, 5 \mathrm{msec}$.

Figure 2. Spiny hilar cells with dendrites in the molecular layer had lower thresholds than neighboring granule cells. $A$, A montage of a fusiform spiny hilar cell is shown. In this figure, and all others, cells were imaged with confocal microscopy (see Materials and Methods). The different sections of the montage are combinations of the optical sections that best illustrate the dendritic tree. The border of the granule cell layer ( $G C L$ ) and the hilus $(H I L)$ is defined by the solid line. At the edge of the photomicrograph, one process turned abruptly and entered the granule cell layer (arrowhead). This cell was located near the upper blade of dorsal hippocampus. Scale bar, $35 \mu \mathrm{m}$. $B$, The extension of the dendritic process marked by an arrowhead in $A$ is shown. The dendrite traveled into the granule cell layer and the molecular layer (arrows). Double arrowheads point to autofluorescent particles and blood vessels. Scale bar (in $A$ ), $75 \mu \mathrm{m}$. $C$, The slice was turned over, and the same area of the slice as in $B$ was imaged. From this orientation, more of the dendritic tree could be observed in the molecular layer (arrows). Same scale as in $B$. $D$, A drawing of the cell that is shown in $A-C$ illustrates its approximate position relative to the granule cell layer (demarcated by solid lines). The arrangement of extracellular recording sites (solid circles, sites $1-4$ ) and stimulating electrode $(S T I M)$ is also shown. $E$, The responses of the cell shown in $A-D$ to a depolarizing and hyperpolarizing current pulse $(0.2 \mathrm{nA}, 150 \mathrm{msec})$ are superimposed. The large $R_{\mathrm{in}}$, long time constant, large depolarizing afterpotential, and frequent spontaneous depolarizing potentials (arrows) are characteristic of spiny hilar cells (Scharfman and Schwartzkroin, 1988). $F$, Simultaneous 

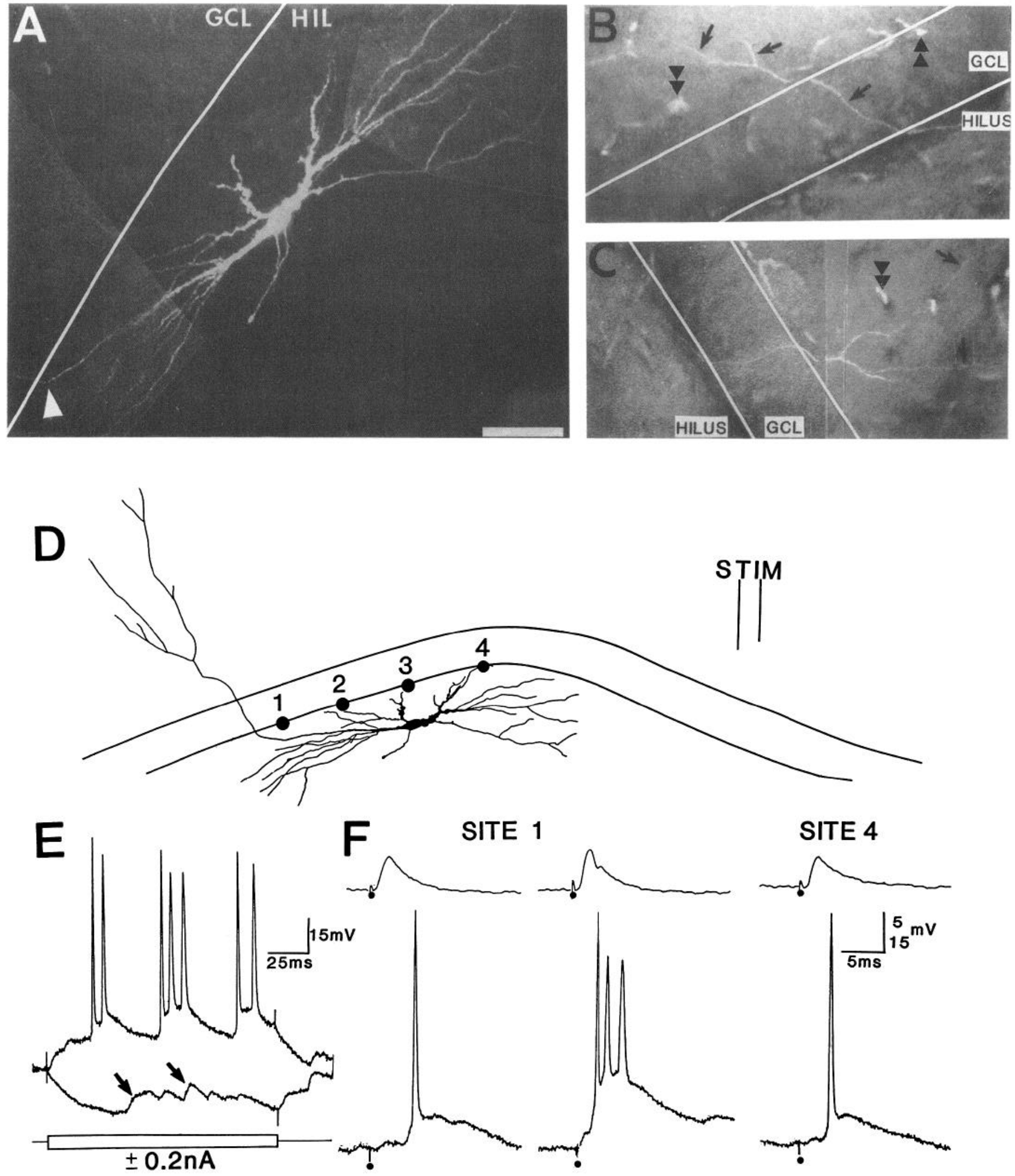

extracellular recordings from the granule cell layer (top) and intracellular recordings from the hilar cell (bottom) shown in $A-D$. Site 1: Left, When the extracellular recording site was near to the area where the hilar cell had dendrites in the molecular layer (site 1 in $D$ ), the cell fired APs at a stimulus intensity that was insufficient to elicit a population spike. Right, When a higher stimulus intensity was tested, a population spike was produced, and the cell fired a burst of three APs. Site 4, When the population spike was recorded closer to the stimulating electrode than the hilar cell body or the hilar cell dendrites in the molecular layer (site 4 in $D$ ), a low-intensity stimulus produced a suprathreshold response in the hilar cell, and a subthreshold potential was recorded from the granule cell layer. Low-stimulus intensity, $0.1 \mathrm{~mA}$; high-stimulus intensity, $0.18 \mathrm{~mA}$; hilar cell RMP, $-67 \mathrm{mV}$. Stimulus artifacts are clipped and marked by small solid circles. 

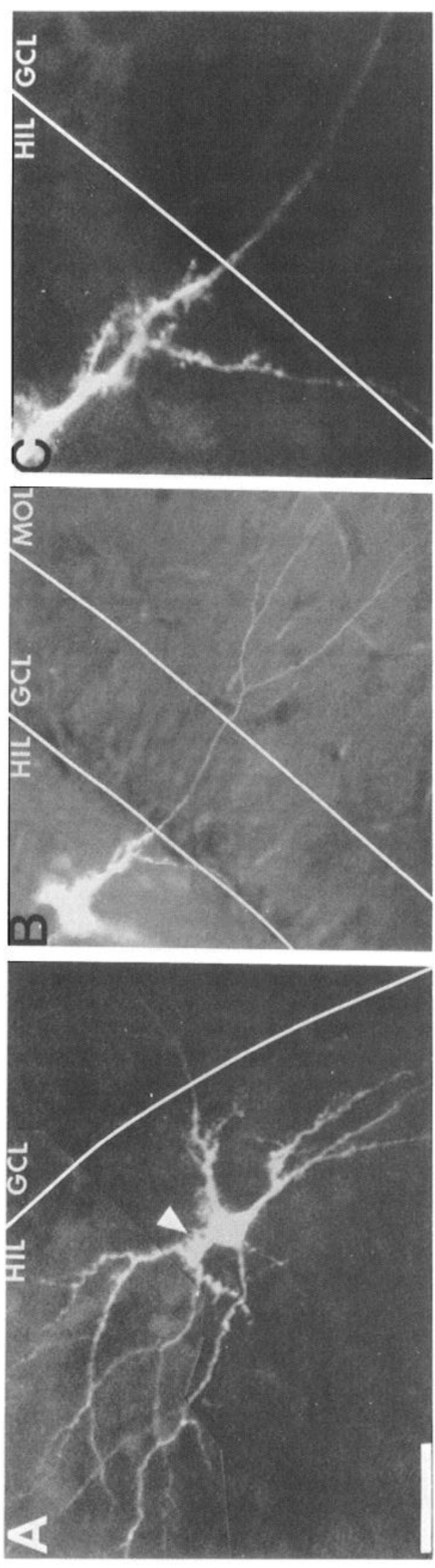
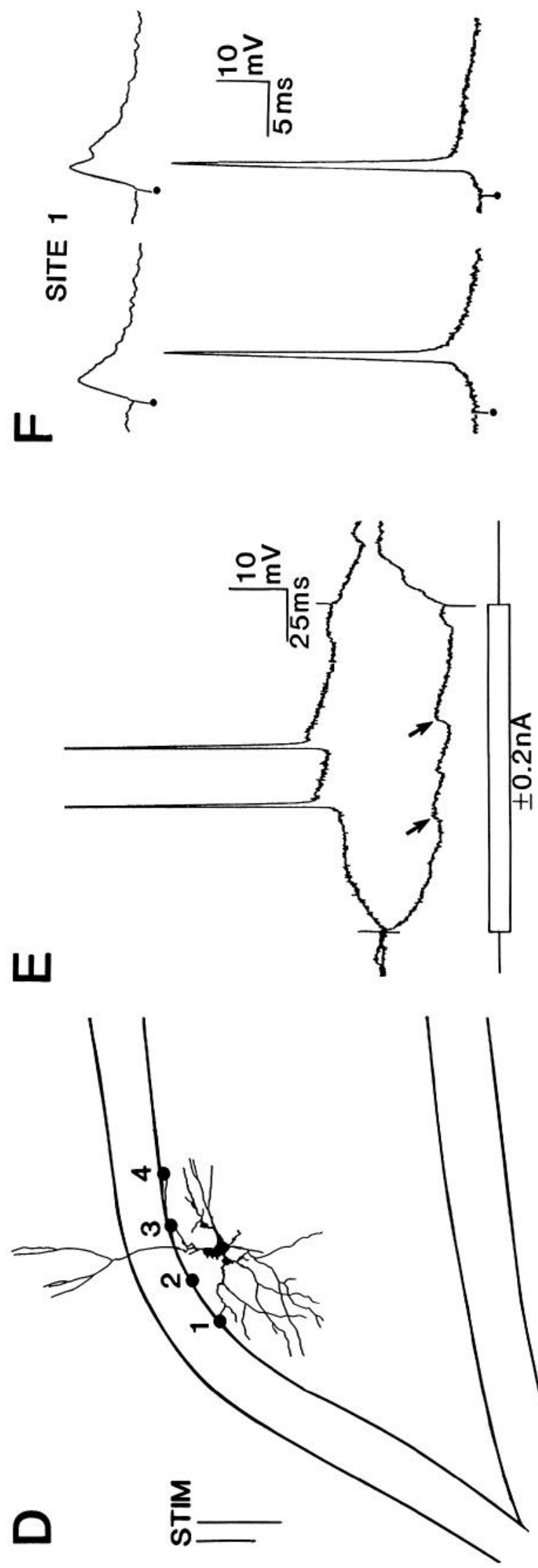

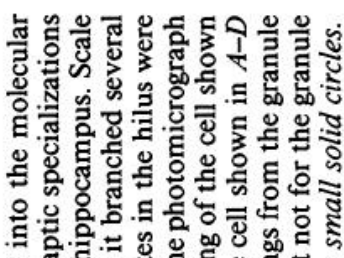

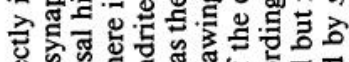

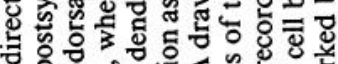

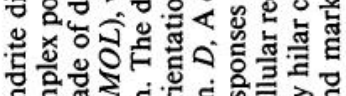

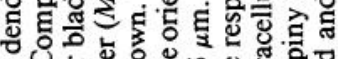
टे

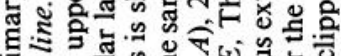

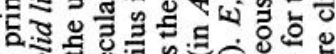
\%

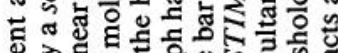
๙

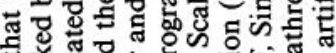

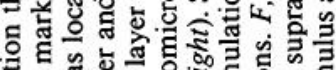

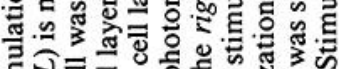

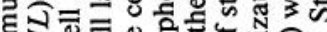

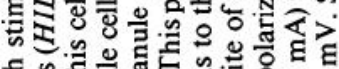

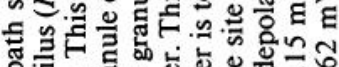

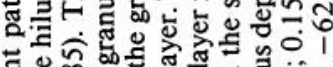
芯舟

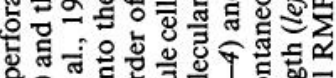
ฝั สี่

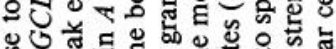
包卷. ชัญ

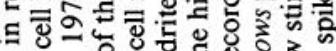

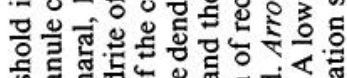

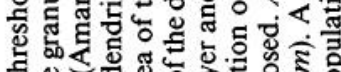

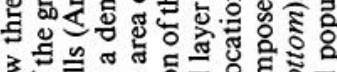

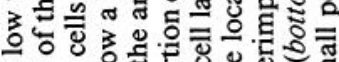

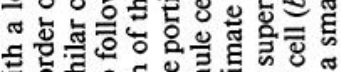

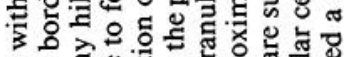

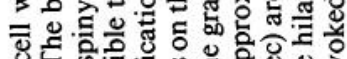

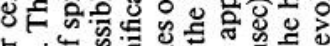

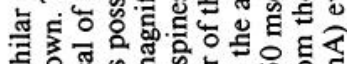
층 త

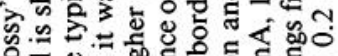

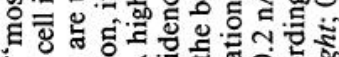

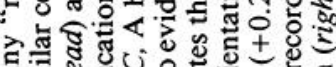

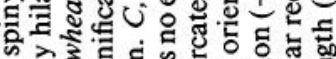

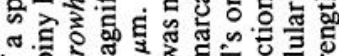

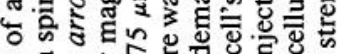

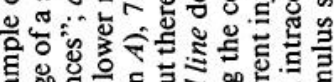

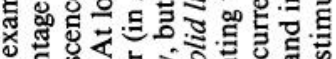
ธ 《

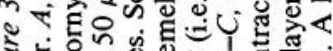

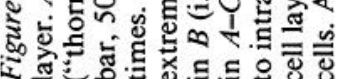



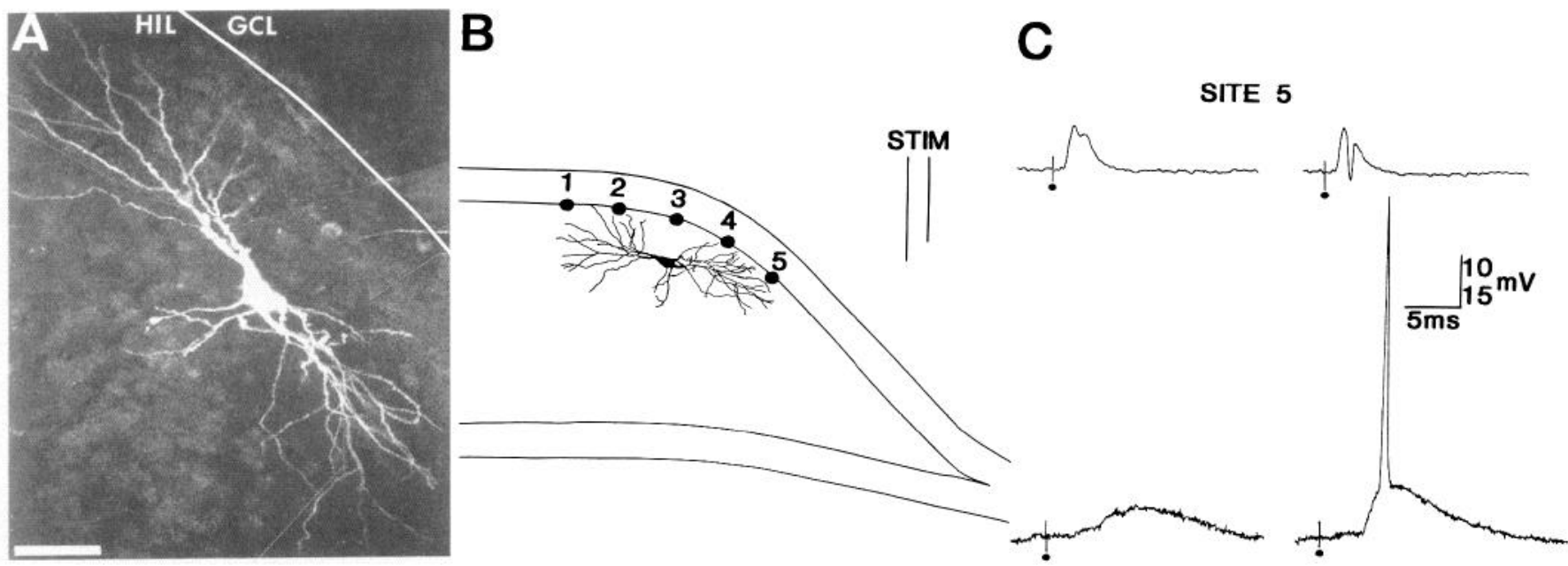

Figure 4. An example of a spiny hilar cell without a low threshold to perforant path stimulation and without detectable dendrites in the molecular layer. A, A montage of a spiny hilar cell is shown. This cell was located near the upper blade in dorsal hippocampus. The solid line demarcates the border of the granule cell layer $(G C L)$ and the hilus $(H I L)$. Scale bar, $25 \mu \mathrm{m}$. B. The orientation of the cell in $A$ is shown, as well as the arrangement of recording (sites $1-5$ ) and stimulating (STIM) electrodes. $C$, The extracellular responses recorded at site 5 (top) and the simultaneous recordings of the cell in $A$ and $B$ (bottom) are shown. A low stimulus strength (left; $0.13 \mathrm{~mA}$ ) produced a small population spike and an EPSP in the cell. A higher stimulus strength (right; $0.25 \mathrm{~mA}$ ) elicited a larger population spike and an AP in the cell. Hilar cell RMP, $-64 \mathrm{mV}$. Stimulus artifacts are clipped and marked with small solid circles.

aspiny cells with undershooting APs that were only $55-60 \mathrm{mV}$. An exception was made because the short AP in "fast-spiking" cells may not reflect injury; as indicated by their particularly large afterhyperpolarizations (AHPs), the short AP may be a result of particularly large repolarizing potassium currents. Several reports of fast-spiking cells have shown that these cells often have relatively short APs (Schwartzkroin and Mathers, 1978; Schwartzkroin and Kunkel, 1985; Lacaille et al., 1987, 1988). Recording sites were distributed throughout the dentate region, near the upper blade or lower blade, or near the region where the two blades meet (Fig. 1A). No differences were detected between hilar neurons sampled in different areas of the hilus (i.e., the area near the upper blade in comparison to the area near the lower blade).

\section{Spiny hilar cells}

\section{Morphology}

Spiny hilar cells $(n=9)$ fell into two categories based on their morphology. One group of cells had fusiform or oval cell bodies, and the dendritic trees were bipolar $(n=3$; Fig. 2). These cells were similar to the fusiform spiny cells described by others (Amaral, 1978; Ribak and Seress, 1988). The second group was similar to the multipolar "mossy" cell that has also been described before ( $n=6$; Fig. 3; Amaral, 1978; Ribak et al., 1985; Scharfman and Schwartzkroin, 1988). Both groups of cells were covered with spines, and their somata and proximal dendrites possessed numerous thorny excrescences (Fig. $3 A$ ). Most spiny hilar cells had extensive dendritic trees in the hilus. In addition, at least one process penetrated the granule cell layer and entered the molecular layer. Typically, only one dendrite passed into the granule cell layer; this dendrite was either a secondary dendrite that made an abrupt turn into the granule cell layer from the parent dendrite (Fig. 2; $n=5$ ), or a primary dendrite that made a straight course for the molecular layer (Fig. $3 ; n=4$ ). In all cases of spiny hilar cells, the dendrite was spiny before entering the granule cell layer and aspinous as it passed through the granule cell layer (Fig. 3). Upon emerging from the granule cell layer and entering the molecular layer, the dendrite of spiny hilar cells did not appear to have spines (Figs. 2, 3) and usually branched several times (Figs. 2, 3). Dendrites that extended into the molecular layer ended in all areas of the molecular layer (i.e., the inner, middle, or outer third), without any obvious pattern that related to other aspects of the cell's physiology or morphology.

\section{Physiology}

As reported for guinea pig hilar cells, the spiny hilar cells of rat possessed homogeneous electrophysiological characteristics, and these characteristics were distinct from those of other cell types of the fascia dentata (Scharfman and Schwartzkroin, 1988). These characteristics included a long time constant, high $R_{\text {in }}$, and virtually continuous spontaneous depolarizing potentials (Figs. 2, 3; see Scharfman and Schwartzkroin, 1988).

All spiny hilar cells with dendrites in the molecular layer had a much lower threshold for AP generation in response to a single stimulus than the threshold for the granule cell population spike. In each experiment, population spikes were recorded in several areas of the granule cell layer in the vicinity of the intracellular electrode (see Materials and Methods; Fig. 1B). After the dendritic tree of the impaled cell was identified by confocal microscopy, the thresholds of the population spikes were compared to the threshold of the cell. Comparisons of threshold were made between population spikes that were recorded closer to the stimulating electrode than the hilar cell body, at an equivalent distance from the stimulating electrode as the cell body, and farther from the stimulating electrode than the cell body. Comparisons could also be made between population spikes recorded at an equivalent distance from the stimulating electrode as the hilar cell dendrite that was situated in the molecular layer. These numerous comparisons were made to control for any difference based merely on distance of the recording site from the stimulating electrode (i.e., if a population spike was recorded farther 

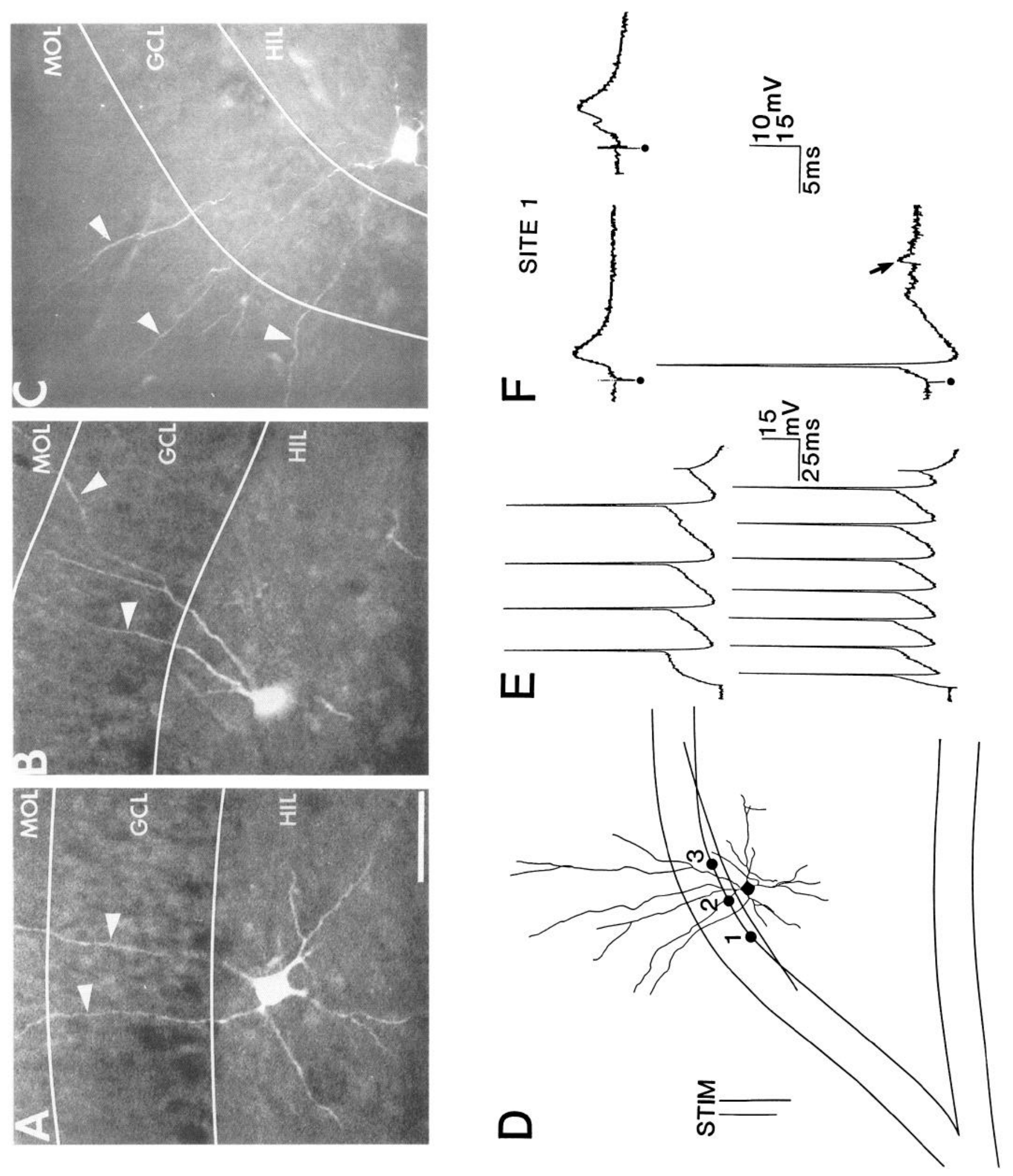
from the stimulating electrode than the hilar cell, it would not be surprising to find that the population spike threshold was higher than the cell threshold). In all comparisons, the threshold of the population spike was much greater than the threshold for AP generation in the impaled cell (Figs. 2, 3). In fact, even when the distance from the stimulating electrode was less for the recording site of the population spike than the hilar cell body or hilar cell dendrites, the threshold for the population spike was still greater than the threshold for AP generation of the impaled neuron (Figs. 2, 3). Cells were tested for their threshold at their RMP, but even when they were hyperpolarized with DC current (up to $0.3 \mathrm{nA}$ ), the threshold for the hilar cell still had a threshold that was lower than the threshold for the population spike recorded in the granule cell layer.

Consistent with the comparison between the threshold of the extracellularly recorded population spike and the intracellularly recorded hilar cell, other experiments involving simultaneous impalements of granule cells and hilar neurons (Scharfman et al., 1990) showed that individual granule cells demonstrated a higher threshold for AP generation following perforant path stimulation than simultaneously recorded spiny hilar cells $(n=$ 4 pairs of different granule cells and hilar cells; data not shown).

In two cases spiny hilar cells did not possess a lower threshold than the granule cell population spike; one of these cells is shown in Figure 4 . In both cells there were no processes apparent in the granule cell layer or the molecular layer, despite the fact that the cells were impaled near the granule cell layer (i.e., Fig. 4). The lack of dendrites in the molecular layer could have occurred because the cells were not adequately filled with dye, but this is unlikely given that the rest of the cells had dendrites that were very well filled (Fig. 4); nevertheless, this possibility cannot be ruled out. An alternate reason for the lack of dendrites in the molecular layer is that the dendritic branch or branches that crossed into the granule cell layer were cut during slice preparation; it is also possible that some hilar cells simply do not possess dendrites in the molecular layer.

\section{Aspiny hilar cells}

The same correlation of sensitivity to perforant path stimuli and presence of dendrites in the molecular layer, described above for spiny hilar cells, was also found for aspiny hilar cells.

\section{Morphology}

Many different morphologies of aspiny cells were represented in our sample of 10 cells. Some of these neurons had a round or multipolar cell body and dendrites extending in all directions ( $n=6$; Fig. 5). Other cells were fusiform cells and were located just below the granule cell layer. Most of the dendrites of these fusiform cells were oriented parallel to the granule cell layer (Fig. 6; $n=4$ ).

The morphology of a typical aspiny hilar cell is shown in Figure 5. Unlike the spiny hilar cells where only one dendrite entered the molecular layer, it was common to trace more than one primary dendrite of aspiny cells in the molecular layer (Fig. 5). Also in contrast to spiny hilar cells, there were some dendrites that branched in the granule cell layer (the dendrites of spiny hilar cells that passed into the molecular layer never branched in the granule cell layer; all branching occurred in the molecular layer; Figs. 2, 3). However, there were some similarities between the dendritic trees of aspiny cells and spiny cclls; one of these similarities was that no spines could be detected on processes in the granule cell layer and molecular layer (Figs. 2, 3 for spiny cells; Figs. 5, 6 for aspiny cells). Another pattern that was similar to some spiny hilar cells was the abrupt turn of a hilar cell dendrite into the granule cell layer (cf. Figs. 2, 6).

\section{Physiology}

The 10 aspiny hilar cells all had very different electrophysiological characteristics from the nine spiny hilar cells. These characteristics were similar to the "fast-spiking" cells recorded by others in area CA1 of hippocampus (Schwartzkroin and Mathers, 1978; Schwartzkroin and Kunkel, 1985; Kawaguchi and Hama, 1987; Lacaille et al., 1987, 1988; Scharfman et al., 1989). However, there was noticeable heterogeneity among the interneurons, in that some were indeed fast-spiking (AP duration, $500 \mu \mathrm{sec}$ ), whereas others had much broader APs (AP duration, 1-2 msec; Figs. 5, 6). Heterogeneity among interneurons has been previously discussed for area CA1 of hippocampus (Kawaguchi and Hama, 1988). However, there were many common characteristics among the aspiny cells that distinguished them clearly from the spiny hilar cells, granule cells, and area CA3 pyramidal cells. These characteristics included a weak capacity for spike frequency adaptation and large, fast AHPs following each AP (Figs. 5, 6).

Most aspiny cells had very low thresholds for AP generation compared to a granule cell population spike that was recorded near to the impaled cell (Figs. 5, 6). Even when the population spike was recorded nearer to the stimulating electrode than the hilar cell's dendrites in the molecular layer, the threshold for the population spike was still greater than the threshold for the

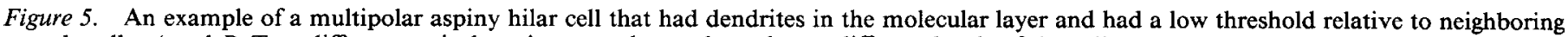

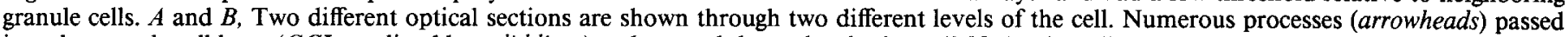

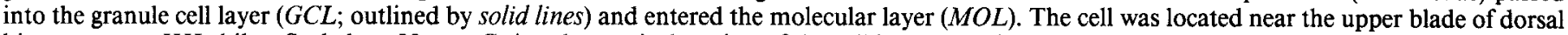

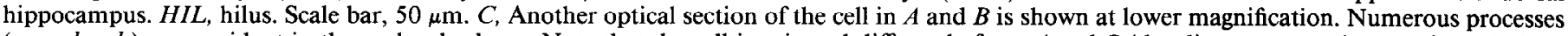

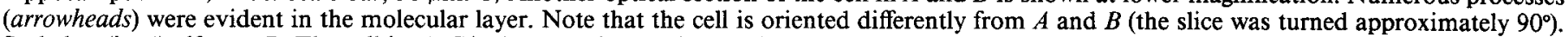

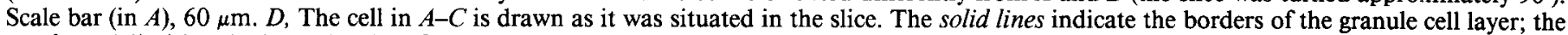

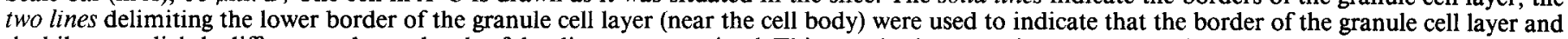

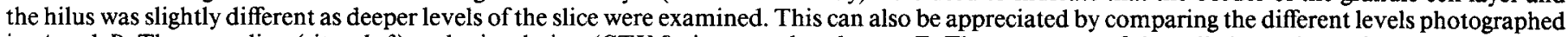

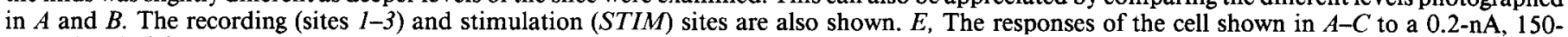

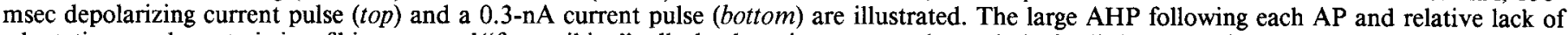

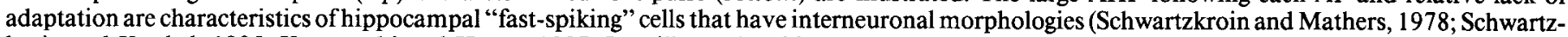

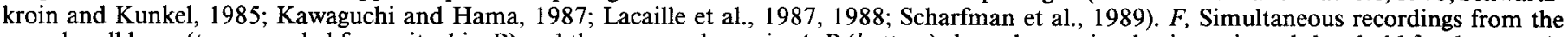

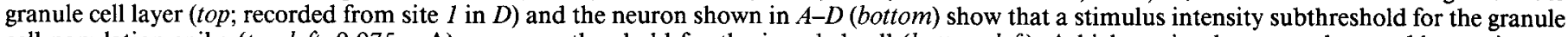

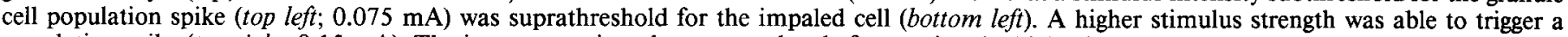

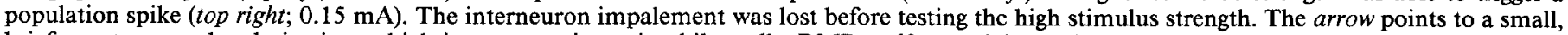

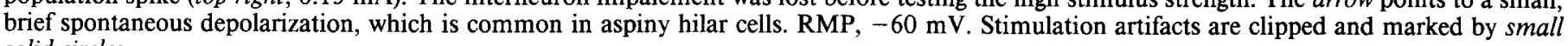
solid circles. 

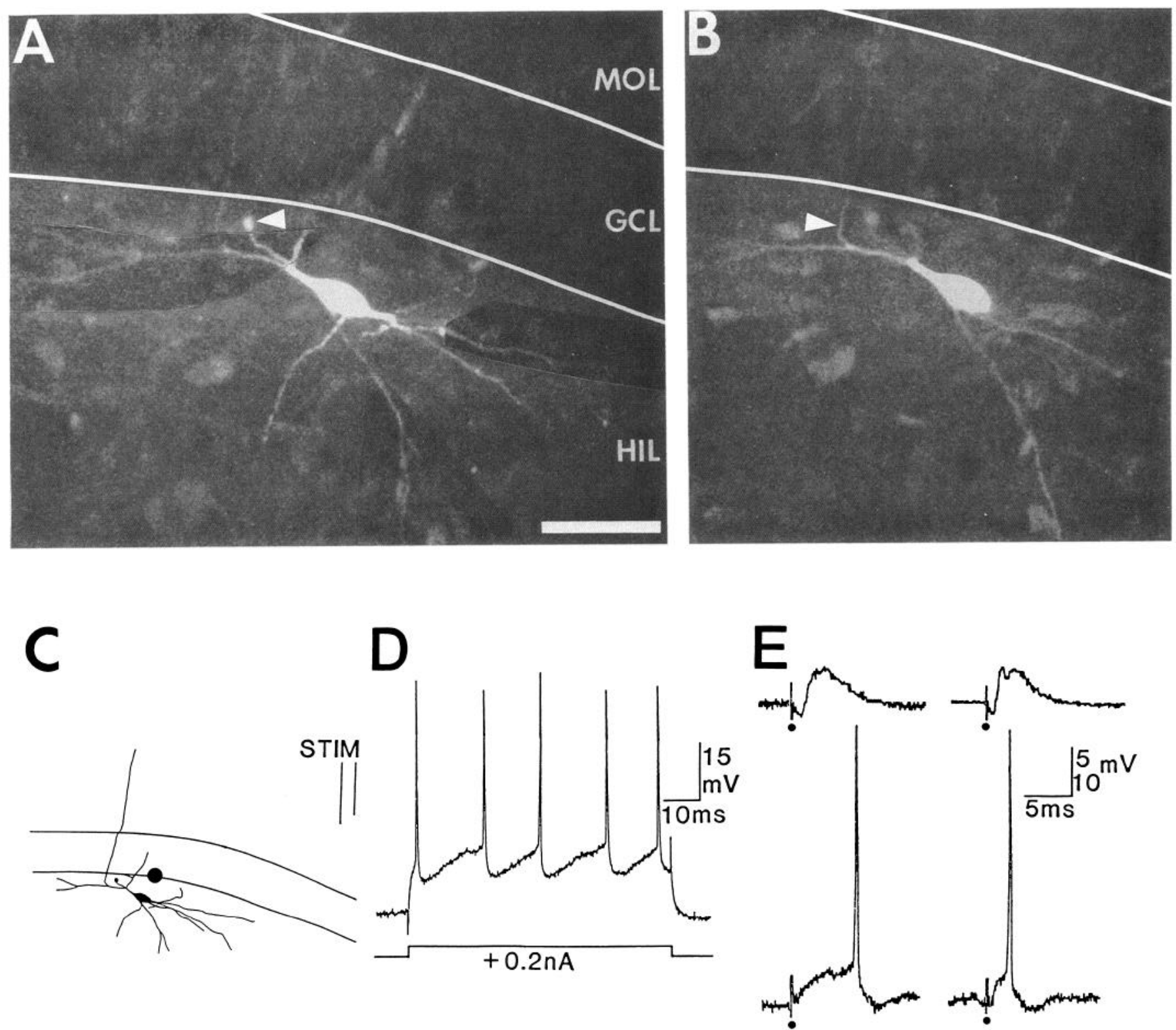

Figure 6. An example of an aspiny fusiform hilar cell with a low threshold in response to perforant path stimulation that had a dendrite that made an abrupt turn into the granule cell layer. $A$, A montage of a fusiform aspiny cell is shown. The arrowhead points to the end of a process that is swelled with fluorescent dye. Because in other cells (where the axon can be identified unequivocally) the cut end of the axon is the only area of the cell where such a "ball" of fluorescence is observed, the arrowhead points to a process that is probably the axon. This cell was located just underneath the upper blade in dorsal hippocampus. $G C L$, granule cell layer; $H I L$, hilus; $M O L$, molecular layer. Scale bar, $50 \mu$ m. $B$, A single optical section through the cell in $A$ illustrates that one dendrite made a sharp turn (arrowhead) from the parent dendrite and entered the granule cell layer. Same scale as in $A$. C. A drawing of the cell in $A$ and $B$, with recording (solid circle) and stimulating (STIM) sites also illustrated. Only one recording site was used in this experiment. $D$, The response of the cell shown in $A-C$ to a +0.2 -nA, 100 -msec current pulse demonstrates that the cell had a firing pattern similar to "fast-spiking" interneurons. $E$, When the outer molecular layer was stimulated, a stimulus that was unable to produce a population spike (top left; $0.12 \mathrm{~mA}$ ) was over threshold for the hilar cell (bottom left). A higher stimulus strength elicited a small population spike $(0.23 \mathrm{~mA}$; top right $)$. RMP, $-54 \mathrm{mV}$. Stimulus artifacts are clipped and marked by small solid circles.

cell (Fig. 5). Only in one case was the threshold of an aspiny cell comparable to the threshold for a granule cell population spike. In this case, there were no dendrites visible in the molecular layer.

The degree of difference of hilar cell thresholds from the threshold of granule cells was similar for all hilar cells, regardless of differences in their morphology. This difference in thresholds was quantified by calculating the mean difference of each spiny or aspiny hilar cell threshold from the mean threshold of the granule cell population spike. The comparison was made based on the population spike recorded closest to the hilar cell dendrites in the molecular layer, to control for distance to the stimulating electrode (see above), which would be expected to play a role in determining threshold. The mean difference for spiny 


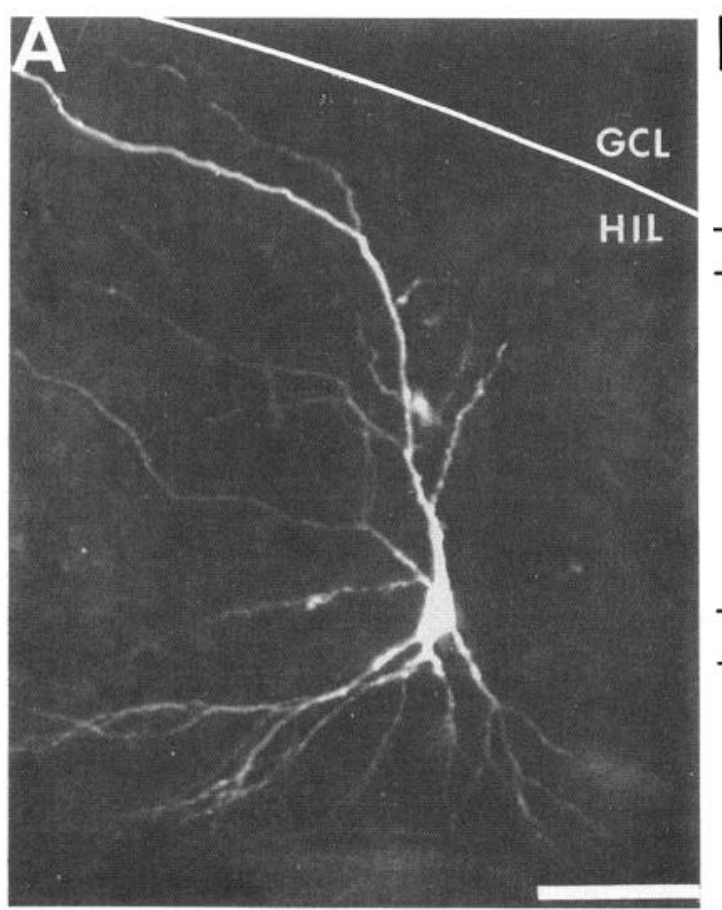

\section{B}
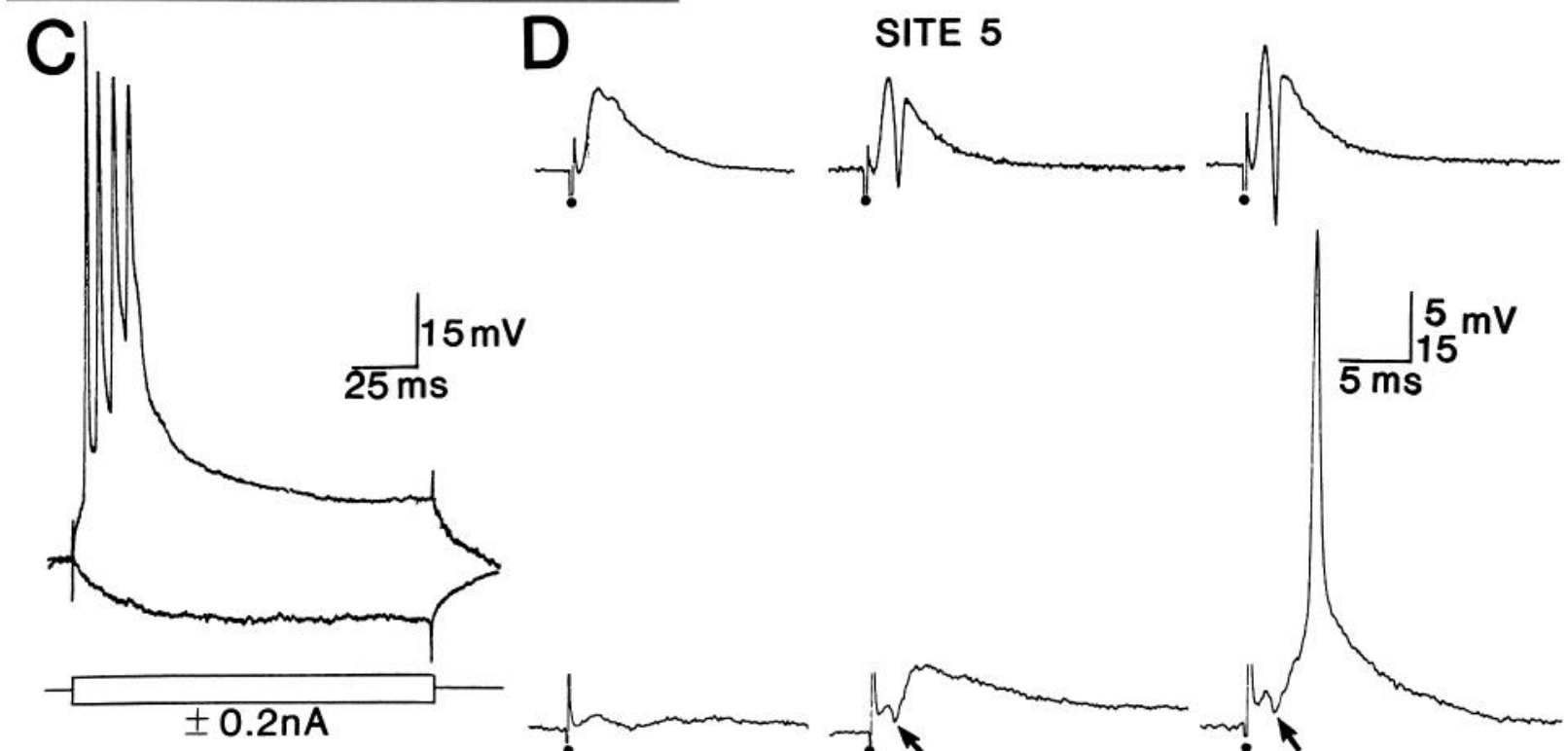

Figure 7. An example of an area CA3c pyramidal cell that had a higher threshold in response to stimulation of the outer molecular layer than the granule cell population spike. $A$, A photomicrograph is shown of an area CA3c pyramidal cell that was impaled on the border of area CA3c and the hilus $(H I L$; see drawing in $B)$. The border of the upper blade of the granule cell layer $(G C L)$ is marked by a solid line. Scale bar, $50 \mu \mathrm{m}$. $B$, The orientation of the cell in $A$ is shown with the approximate sites of recording (sites $1-5$ ) and stimulation (STIM). $C$, The cell shown in $A$ and $B$ produced a burst in response to depolarizing intracellular current injection $(+0.2 \mathrm{nA}, 150 \mathrm{msec})$. This bursting behavior is common among area CA3 cells (Bilkey and Schwartzkroin, 1990). D. Simultaneous extracellular responses (top) recorded at site 5 as shown in $B$ and from the cell shown in $A$ and $B$ (bottom). Responses are shown following a low (left; $0.15 \mathrm{~mA})$, intermediate (center; $0.2 \mathrm{~mA})$, and high (right; $0.4 \mathrm{~mA})$ intensity stimulus. The arrows point to the reflections of the granule cell population spikes in the intracellular records. Stimulus artifacts are clipped and marked by small solid circles.

hilar cells (mean $\pm \mathrm{SEM}, 0.77 \pm 0.16 \mathrm{~mA})$ was not different from the mean difference for aspiny hilar cells $(0.86 \pm 0.32$ $\mathrm{mA} ; t$ test, $p>0.05$ ).

\section{Area CA3c pyramidal cells}

As has been noted previously (Scharfman and Schwartzkroin, 1988), the cells of area CA3c have similar electrophysiological characteristics as spiny hilar cells, but possess less spontaneous activity and usually possess a shorter time constant and lesser $R_{\text {in }}$ (Fig. 7C). Despite these similarities in membrane properties, the responses to stimulation of the perforant path were very different from spiny hilar cells.

\section{Morphology}

Area CA3c cells $(n=4)$ were impaled in the area CA3c cell layer or within $100 \mu \mathrm{m}$ of the border of the CA3c cell layer and 
the hilus. An extension of $100 \mu \mathrm{m}$ was given because the borders of the area CA $3 \mathrm{c}$ cell layer in slices are not always distinct. Cells were impaled near the end of the pyramidal cell layer, close to the hilus (Fig. 7). Not all cells in this area of the CA3c pyramidal cell layer have a classical pyramidal cell shape (Amaral, 1978), so we set a few criteria to define a cell as an area CA3c pyramidal cell. We defined a cell as an area CA3c pyramidal cell if it had a cell body in the cell layer or within $100 \mu \mathrm{m}$ of the cell layer and possessed a dendritic orientation similar to CA3 pyramidal cells (i.e., with a large "apical" dendritic tree pointed toward the upper blade and a basal dendritic tree extended toward the lower blade; Fig. 1A). One of the more classically shaped area CA3c pyramidal cells is illustrated in Figure $7 \mathrm{~A}$.

\section{Physiology}

When the outer molecular layer was stimulated, area CA3c cells responded with a longer delay and an equivalent (or higher) threshold for AP generation than simultaneously recorded granule cell population spikes (Fig. 7). When comparing the population spike and an area $\mathrm{CA} 3 \mathrm{c}$ cell, many recording sites in the granule cell layer were tested (Figs. $1 B, 7$ ), and in no case did the threshold for the population spike exceed the threshold for an $\mathrm{AP}$ in the impaled CA3c cell. Even when there was a large distance from the stimulating electrode to the recording site in the granule cell layer, the threshold of the population spike was still less than the threshold of the area CA3c cell (Fig. 7).

\section{Discussion}

In summary, all hilar cells with dendrites in the molecular layer had very low thresholds for AP generation following single perforant path stimuli, in comparison to granule cells. In contrast, all cells without dendrites in the molecular layer did not have low thresholds. These correlations applied to the spiny hilar cells as well as the aspiny hilar cells. The results suggest that (1) many hilar cells have dendrites in the molecular layer, and (2) these dendrites are functionally significant.

Recent reports have shown that some dendrites of aspiny, somatostatin-immunoreactive (Léránth et al., 1990), or parvalbumin-immunoreactive (Zipp et al., 1989) hilar cells exist in the molecular layer, and earlier studies have indicated that dendrites in the molecular layer may exist for a few aspiny and spiny hilar cells (Amaral, 1978; Ribak et al., 1985). In addition, Zipp et al. (1989) have shown that entorhinal fibers form synapses on dendrites on some of the aspiny, parvalbumin-immunoreactive hilar cells. These studies, in conjunction with the results presented here, strongly suggest that hilar cell dendrites in the molecular layer are innervated by perforant path axons.

Why do hilar cells have a lower threshold for synaptic activation by the perforant path than granule cells?

It is not clear why a hilar cell would have a much lower threshold than a granule cell, because the en passant terminals of perforant path fibers in the outer molecular layer appear homogeneous.

\section{Circuitry considerations}

One likely explanation for the relatively low threshold of hilar cells with dendrites in the molecular layer is that the perforant path innervates hilar cells directly, as well as via granule cells. Granule cells of the rodent, in contrast, are only excited by perforant path stimuli directly. However, one might expect that the direct perforant path innervation would only provide a weak source of excitation to hilar cells. This would be expected be- cause perforant path axons can only innervate a fraction of the hilar cell dendritic tree, and these synapses are a long distance from the hilar cell body. It is also predicted from some of the results presented that the perforant path only excites hilar cells weakly. Given that the EPSP occurring immediately after a stimulus reflects the activity of the perforant path-to-hilar cell synapses, it is relevant that the APs of hilar cells often occurred after the initial EPSPs reached their peaks (Figs. 2, 6). The additional observation that initial EPSPs were sometimes quite small in amplitude (Fig. 2) also supports the hypothesis that the perforant path innervation of hilar cells provides a weak source of excitation. In contrast, large depolarizations, which usually triggered APs, often occurred at a similar latency as the granule cell population spike (Figs. 2, 4, 6). The relatively large excitatory effect of the granule cell-to-hilar cell synapsc is consistent with the enormity of mossy fiber boutons compared to perforant path boutons (Blackstad, 1963). In conclusion, the direct perforant path input may only produce a small depolarization in hilar cells, but this excitation may provide enough of a "boost" to the hilar cell that the strong, subsequent excitation via granule cells exceeds threshold.

Other aspects of the circuitry of the fascia dentata may provide additional explanations for the low threshold of hilar cells. For example, perforant path stimulation may activate strong feedforward inhibitory synapses on granule cells that do not exist on hilar cells. Therefore, a perforant path stimulus would be expected to excite hilar cells at a time when granule cells would be inhibited. This hypothesis, that interneurons activated by perforant path may contribute to feedforward inhibition of granule cells, is supported by our data that many hilar aspiny, "fastspiking" cells (putative inhibitory intcrncurons) are activated by perforant path stimulation at short latencies (Fig. 5), and that hilar "fast-spiking" cells produce IPSPs in granule cells (Scharfman et al., 1990). The relative deficiency in synaptic inhibition of hilar cells, as compared with granule cells, is supported by the lack of hyperpolarizations (IPSPs) in hilar neurons following stimulation of the perforant path. Granule cells impaled in the same slices exhibited robust IPSPs, even with $\mathrm{LiCl}$ in the intracellular electrodes (data not shown). Numerous studies have documented the presence of strong feedforward inhibition in the dentate (Buzsàki and Eidelberg, 1981; Buzsàki, 1984; Frotscher et al., 1984; Seress and Ribak, 1984; Zipp et al., 1989).

Another possible explanation for the difference in threshold is based on the aspinous appearance of hilar cell dendrites in the molecular layer, which contrasts with the spiny dendrites of granule cells. Although higher-resolution studics must be implemented to demonstrate definitively a complete lack of spines on hilar cell dendrites in the molecular layer, it is likely that many of the dendrites are aspinous, and that therefore the synaptic contacts of perforant path fibers occur on hilar cell dendritic shafts. Assuming that a spine neck is a path of high resistance, cable theory would predict that hilar cell EPSPs would decay less than granule cell EPSPs during their journey from the synapse to the soma. Therefore, given a similar synaptic depolarization, hilar cells would be expected to have a lower threshold than granule cells. However, the site of the perforant path synapse is farther from the cell body of a hilar cell than a granule cell. Therefore, a difference in shaft versus spine innervation might be outweighed by the distance that must be traveled from the site of innervation to the cell body. Furthermore, it would be expected that the number of en passant synapses 
from perforant path fibers would be far greater on a given granule cell than a given hilar cell, because all of the dendrites of a granule cell are innervated by perforant path, whereas only a fraction of the hilar cell dendritic tree could be innervated by the perforant path.

Another aspect of dentate circuitry that may be important in determining the low threshold of hilar cells is the apparent bombardment of hilar cells by excitatory transmitter. The results of this tonic excitatory input are large, frequent, spontaneous EPSPs that are observed in all spiny hilar cells and, to a lesser degree, in aspiny hilar cells (Figs. 2, 3, 5). It is likely that spontaneous release of transmitter from granule cell nerve terminals is responsible for this spontaneous activity (Scharfman et al., 1990). Thus, any stimulus to the perforant path is likely to elicit an EPSP that would sum with a spontaneous EPSP, and the resulting depolarization could exceed threshold. Because this continuous background of excitatory input is not found in granule cells, it could explain the lower threshold of hilar cells compared to granule cells.

\section{Intrinsic properties}

Other explanations for the low threshold of hilar cells are based on the different intrinsic properties of hilar cells and granule cells. For example, both spiny and aspiny hilar cells have higher $R_{\text {in }}$ values than granule cells (granule cells, 50-70 M $\Omega$; hilar cells, 90-150 M $\Omega$; Scharfman and Schwartzkroin, 1989). Assuming that the characteristics of perforant path synapses on hilar cells and granule cells are similar and that these cells have a similar postsynaptic receptor distribution, it would be expected that the depolarization produced in a hilar cell would be larger than the depolarization of a granule cell. It is also clear that granule cells have a much more hyperpolarized RMP than hilar cells, at least as recorded in slice preparations (granule cells, -70 to $-80 \mathrm{mV}$; hilar cells, -50 to $-70 \mathrm{mV}$; Scharfman and Schwartzkroin, 1989; Lambert and Jones, 1990). These two factors alone, $R_{\text {in }}$ and RMP, could explain the lower threshold of hilar cells as compared with granule cells.

One may also speculate on other intrinsic properties that may be important in determining threshold. For example, active conductances may be present in the hilar cell dendrites but not in granule cell dendrites. Another characteristic of many hilar cells is that they have a low level of the calcium-binding proteins parvalbumin and calbindin relative to granule cells (Baimbridge and Miller, 1982; Kosaka et al., 1987; Sloviter, 1989). Several studies have provided evidence that hilar cells that lack these calcium-binding proteins may be particularly sensitive to repetitive perforant path stimulation (Sloviter, 1987, 1989; Scharfman and Schwartzkroin, 1989). It is possible that the lack of calcium-binding proteins may also underlie sensitivity to single stimuli. In this regard, it is particularly relevant that one of the calcium-binding proteins, parvalbumin, stains the dendrites of immunoreactive cells, suggesting that parvalbumin could be present near synapses and regulate changes in intracellular calcium that occur immediately after a single stimulus. However, very little is known about the physiological role of calciumbinding proteins, and therefore this possibility is merely conjecture at this time.

Finally, it is possible that aspects of the recording arrangement were responsible for low hilar cell thresholds. It is possible that the granule cells situated directly beneath our stimulating electrode were activated by current spread from the stimulating electrode, even at low stimulus intensities that were insufficient to discharge granule cells that were located closer to the hilar cell. It is possible that the granule cells that were activated directly made excitatory connections on the hilar cell that was recorded in that slice. If so, a perforant path stimulus might result in an EPSP due to perforant path innervation of the hilar cell, as well as an EPSP due to the granule cell innervation of the hilar cell. The summation of these two EPSPs might have produced a suprathreshold depolarization in the hilar cell.

\section{Relationship to previous studies of the dentate region}

This study presents some data that differ from morphological descriptions of hilar neurons reported previously. The finding that most hilar cells have processes that pass into the molecular layer differs from the Golgi study of Amaral (1978), and our previous findings in guinea pig (Scharfman and Schwartzkroin, 1988), where the dendrites of most hilar cells were confined to the hilus. One possible reason for this discrepancy may be that the thick sections $(400 \mu \mathrm{m})$ and confocal microscopy used in this report allowed the distal dendrites in the molecular layer to be visualized more easily than the thinner sections used in the Golgi study or the conventional epifluorescence techniques used in the guinea pig study. In support of these possibilities, we found that the dendritic segment that crossed into the granule cell layer and the molecular layer was always in a distant optical section from the cell body (Fig. $2 B, C$ ).

\section{Applicability to hippocampal physiology in vivo}

Whether our data are representative of the hilus in vivo is debatable. It is not clear that all cell types present in the hilus were sampled, or that the numbers of cells impaled are representative of the proportions of the cell types that are found in vivo. This is especially the case for "fast-spiking" interneurons, which are notoriously difficult to detect and impale with standard intracellular techniques. It is possible that some types of hilar cells were not sampled, because it has been shown that many hilar cells are subject to damage during anoxic periods (Johansen et al., 1986; Benveniste and Diemer, 1988; Crain et al., 1989), and some period of anoxia is inevitable during the slicing procedure. However, most of the known hilar cell types have been recorded from: spiny fusiform, spiny "mossy," aspiny multipolar, and aspiny fusiform. Also, because most hilar cells that were studied were extremely sensitive to perforant path stimulation, it might be argued that the hilar cells that are susceptible to excitotoxic damage were indeed preserved in our slices.

However, the fact that slice preparation by definition severs many afferent systems to the hilar cells and granule cells (Buzsàki and Eidelberg, 1981; Douglas et al., 1983; Frotscher et al., 1984; Köhler et al., 1984; Bilkey and Goddard, 1987) cannot be denied. One important example is the loss of the GABAergic commissural projection (Buzsàki and Eidelberg, 1981; Douglas et al., 1983; Frotscher et al., 1984; Seress and Ribak, 1984; Ribak et al., 1986; Bilkey and Goddard, 1987). Because this pathway may contribute to inhibitory potentials of dentate cells, differences in threshold obtained in the absence of such projections may not apply to the situation in vivo. It is known from electron microscopy of HRP-filled hilar cells that spiny and aspiny cells receive numerous symmetric contacts (Kunkel et al., 1988; D. D. Kunkel, H. E. Scharfman, and P. A. Schwartzkroin, unpublished observations), and immunocytochemistry of guinea pig dentate gyrus has shown GABA-immunoreactive contacts on hilar cells (Misgeld and Frotscher, 1986). If those inhibitory connections were severed in our slices, then a low hilar cell 
threshold might be recorded in slices, but not occur in vivo. In an effort to circumvent this problem, only slices with strong paired-pulse inhibition were used in this study (see Materials and Methods), so we could be confident that recurrent inhibition was present. However, though the presence of paired-pulse inhibition indicated that recurrent inhibition was functional, it does not necessarily imply that feedforward inhibition was present.

Despite these issues, the results suggest that the circuitry of the fascia dentata is appropriately designed to act as a filter, where weak excitatory signals pass easily to the sensitive hilar cells but do not excite granule cells. Only higher-intensity stimuli may cause granule cells to fire (and if such high-intensity stimulation is prolonged, the excitotoxic insult may cause damage and possibly death of susceptible hilar neurons). Because many hilar neurons project to distant ipsilateral sites in the inner molecular layer, as well as the contralateral inner molecular layer (Blackstad, 1956; Zimmer, 1971; Swanson et al., 1978; Laurberg and Sørensen, 1981), one might predict that weak stimulation by perforant path would activate distant sites in the ipsilateral and the contralateral hippocampus (via hilar cell projections) without activating the trisynaptic pathway in the "lamella" containing the active perforant path fibers. This scenario underscores recent suggestions that hippocampal activity may not be restricted to the trisynaptic pathway according to a strictly lamellar hippocampal organization (Amaral and Witter, 1989; Yeckel and Berger, 1990).

\section{References}

Amaral DG (1978) A Golgi study of the cell types in the hilar region of the hippocampus in the rat. J Comp Neurol 182:851-914.

Amaral DG, Witter MP (1989) The three dimensional organization of the hippocampal formation: a review of anatomical data. Neuroscience 31:571-591.

Andersen P, Holmqvist B, Voorhoeve PE (1966) Entorhinal activation of dentate granule cells. Acta Physiol Scand 66:448-460.

Andersen P, Bliss TVP, Skrede KK (1971) Unit analysis of hippocampal population spikes. Exp Brain Res 13:208-221.

Baimbridge KG, Miller JJ (1982) Immunohistochemical localization of calcium-binding protein in the cerebellum, hippocampal formation and olfactory bulb of the rat. Brain Res 245:223-229.

Benveniste H, Diemer NH (1988) Early postischemic ${ }^{45} \mathrm{Ca}$ accumulation in rat dentate hilus. J Cereb Blood Flow Metab 8:713-719.

Bilkey DK, Goddard GV (1987) Septohippocampal and commissural pathways antagonistically control inhibitory interneurons in the dentate gyrus. Brain Res 405:320-325.

Bilkey DK, Schwartzkroin PA (1990) Variation in electrophysiology and morphology of hippocampal CA3 pyramidal cells. Brain Res 514: 77-83.

Blackstad TW (1956) Commissural connections of the hippocampal region of the rat, with special reference to their mode of termination. J Comp Neurol 105:417-537.

Blackstad TW (1963) Ultrastructural studies on the hippocampal region. Prog Brain Res 3:122-148.

Buzsàki G (1984) Feed-forward inhibition in the hippocampal formation. Prog Neurobiol 22:131-153.

Buzsaki G, Eidelberg E (1981) Commissural projection to the dentate gyrus of the rat: evidence for feed-forward inhibition. Brain Res 230: 346-350.

Crain BJ, Westerkam WD, Harrison AH, Nadler JV (1988) Selective neuronal death after transient forebrain ischemia in the Mongolian gerbil: a silver impregnation study. Neuroscience 27:387-402.

Douglas RM, McNaughton BL, Goddard GV (1983) Commissural inhibition and facilitation of granule cell discharge in fascia dentata. J Comp Neurol 219:285-294.

Frotscher M, Léránth C, Lübbers K, Oertel WH (1984) Commissural afferents innervate glutamate decarboxylase immunoreactive nonpyramidal neurons in the guinea pig hippocampus. Neurosci Lett 46: 137-143.
Hjorth-Simonsen A (1973) Projection of the lateral part of the entorhinal area to the hippocampus and fascia dentata. J Comp Neurol 146: 219-232.

Johansen FF, Zimmer J, Diemer NH (1987) Early loss of somatostatin neurons in the dentate hilus after cerebral ischemia in the rat precedes CA-1 pyramidal cell loss. Acta Neuropathol [Berl] 73:110-114.

Kawaguchi Y, Hama K (1987) Fast-spiking non-pyramidal cells in the hippocampal CA3 region, dentate gyrus, and subiculum of rats. Brain Res 425:351-355.

Kawaguchi Y, Hama K (1988) Physiological heterogeneity of nonpyramidal cells in rat hippocampal CA1 region. Exp Brain Res 72: 494-502.

Köhler C, Chan-Palay V (1982) Somatostatin-like immunoreactive neurons in the hippocampus: an immunocytochemical study in the rat. Neurosci Lett 34:259-264.

Köhlcr D, Eriksson LG, Davies S, Chan-Palay V (1986) Neuropeptide $Y$ innervation of the hippocampal region in the rat and monkey brain. J Comp Neurol 244:384-400.

Kosaka T, Katsumaru H, Hama K, Wu J-Y, Heizmann CW (1987) GABAergic neurons containing the $\mathrm{Ca}^{2+}$ binding protein parvalbu$\mathrm{min}$ in the rat hippocampus and dentate gyrus. Brain Res 419:119130.

Kunkel DD, Scharfman HE, Schwartzkroin PA (1988) Ultrastructure of intracellularly labelled mossy cells of the rat dentate gyrus. Soc Neurosci Abstr 14:770.

Lacaille J-C, Mueller AL, Kunkel DD, Schwartzkroin PA (1987) Local circuit interactions between oriens/alveus interneurons and CAl pyramidal cells in hippocampal slices: electrophysiology and morphology. J Neurosci 7:1979-1993.

Lacaille J-C, Kunkel DD, Schwartzkroin PA (1988) Stratum lacunosum-moleculare interneurons of hippocampal CAl region: I. Intracellular response characteristics, synaptic responses, and morphology. J Neurosci 8:1632-1644.

Lambert JDC, Jones RSG (1990) A reevaluation of excitatory amino acid-mediated synaptic transmission in rat dentate gyrus. J Neurophysiol 64:119-132.

Laurberg S, Sørensen K (1981) Associational and commissural collaterals of neurons in the hippocampal formation (hilus fasciae dentatae and subfield CA3). Brain Res 212:287-300.

Léránth C, Malcolm AJ, Frotscher M (1990) Afferent and efferent synaptic connections of somatostatin-immunoreactive neurons in the rat fascia dentata. J Comp Neurol 295:111-122.

Lomo T (1971) Patterns of activation in a monosynaptic cortical pathway: the perforant path input to the dentate area of the hippocampal formation. Exp Brain Res 12:18-45.

McNaughton BL, Barnes CA (1977) Physiological identification and analysis of dentate granule cell responses to stimulation of the medial and lateral perforant pathways in the rat. J Comp Neurol 175:439454.

Meldrum BS, Corsellis JAN (1985) Epilepsy. In: Greenfield's neuropathology (Adams JH, Corsellis JAN, Duchen LW, eds), pp 921-950. New York: Wiley.

Misgeld U, Frotscher M (1986) Postsynaptic-GABAergic inhibition of non-pyramidal neurons in the guinea pig hippocampus. Neuroscience 19:193-206.

Naus CCG, Morrison JH, Bloom FE (1988) Development of somatostatin-containing neurons and fibers in the rat hippocampus. Dev Brain Res 40:113-121.

Olney JW, de GubareffT, Sloviter RS (1983) "Epileptic" brain damage in rats induced by sustained electrical stimulation of the perforant path. II. Ultrastructural analysis of acute hippocampal pathology. Brain Res Bull 10:699-712.

Ribak CE, Seress L (1988) A Golgi-electron microscopy study of fusiform neurons in the hilar region of the dentate gyrus. J Comp Neurol 271:67-78

Ribak CE, Seress L, Amaral DG (1985) The development, ultrastructure and synaptic connections of the mossy cells of the dentate gyrus. J Neurocytol 14:835-857.

Ribak CE, Seress L, Peterson G, Seroogy KB, Fallon JH, Schmued LC (1986) A GABAergic inhibitory component within the hippocampal commissural pathway. J Neurosci 6:3492-3498.

Scharfman HE, Schwartzkroin PA (1988) Electrophysiology of morphologically identified mossy cells recorded in the dentate hilus in guinea pig hippocampal slices. J Neurosci 8:3412-3421.

Scharfman HE, Schwartzkroin PA (1989) Protection of dentate hilar cells from prolonged stimulation by intracellular calcium chelation. Science 246:257-260. 
Scharfman HE, Schwartzkroin PA (1990) Consequences of prolonged afferent stimulation of the rat fascia dentata: epileptiform activity in area CA3 of hippocampus. Neuroscience 35:505-517.

Scharfman HE, Kunkel DD, Schwartzkroin PA (1989) Intracellular dyes mask immunoreactivity of hippocampal interneurons. Neurosci Lett $96: 23-28$.

Scharfman HE, Kunkel DD, Schwartzkroin PA (1990) Synaptic connections of dentate granule cells and hilar neurons: results of paired intracellular recordings and intracellular horseradish peroxidase injections. Neuroscience 37:693-707.

Schwartzkroin PA, Kunkel DD (1985) Morphology of identified interneurons in the CAl region of the guinea pig hippocampus. J Comp Neurol 232:205-218.

Schwartzkroin PA, Mathers L (1978) Physiological and morphological identification of a nonpyramidal hippocampal cell type. Brain Res 157:1-10.

Seress L, Ribak CE (1984) Direct commissural connections to the basket cells of the hippocampal dentate gyrus: anatomical evidence for feedforward inhibition. J Neurocytol 13:215-225.

Sloviter RS (1983) "Epileptic" brain damage in rats induced by sustained electrical stimulation of the perforant path. I. Acute electrophysiological and light microscopical studies. Brain Res Bull 10:675697.

Sloviter RS (1987) Decreased hippocampal inhibition and a selective loss of interneurons in experimental epilepsy. Science 235:173-176. Sloviter RS (1989) Calcium binding protein (calbindin $\mathrm{D}_{28} \mathrm{~K}$ ) and parvalbumin immunocytochemistry: location in the rat hippocampus with specific reference to selective vulnerability of hippocampal neurons to seizure activity. J Comp Neurol 280:183-196.

Sloviter RS, Nilaver G (1987) Immunocytochemical localization of GABA-, CCK-, VIP-, and somatostatin-like immunoreactivity in the area dentata and hippocampus of the rat. J Comp Neurol 256:42-60.

Steward O, Scoville SA (1976) Cells of origin of entorhinal afferents to hippocampus and fascia dentata of the rat. J Comp Neurol 169: 347-370.

Swanson L, Wyss JM, Cowan MW (1978) An autoradiographic study of the organization of intrahippocampal association pathways in the rat. J Comp Neurol 181:681-71.

Yeckel MF, Berger TW (1990) Feedforward excitation of the hippocampus by afferents from the entorhinal cortex: redefinition of the role of the trisynaptic pathway. Proc Natl Acad Sci USA 87:58325836.

Zimmer J (1971) Ipsilateral afferents to the commissural zone of the fascia dentata, demonstrated in decommissurated rats by silver impregnation. J Comp Neurol 142:393-416.

Zipp F, Nitsch R, Soriano E, Frotscher M (1989) Entorhinal fibers form synaptic contacts on parvalbumin-immunoreactive neurons in the rat fascia dentata. Brain Res 495:161-166. 